\begin{tabular}{l} 
RCCS \\
\hline Annual Review
\end{tabular}

\section{RCCS Annual Review}

A selection from the Portuguese journal Revista Crítica de Ciências Sociais

6 | 2014

Issue no. 6

\title{
My Money, Your Money, Our Money: \\ Contributions to the Study of Couples' Financial Management in Portugal
}

\section{Lina Coelho}

Translator. Karen Bennett

\section{OpenEdition}

\section{Journals}

Electronic version

URL: http://journals.openedition.org/rccsar/546

DOI: $10.4000 /$ rccsar.546

ISSN: $1647-3175$

\section{Publisher}

Centro de Estudos Sociais da Universidade de Coimbra

\section{Electronic reference}

Lina Coelho, « My Money, Your Money, Our Money: Contributions to the Study of Couples' Financial

Management in Portugal », RCCS Annual Review [Online], 6 | 2014, Online since 01 October 2014, connection on 01 May 2019. URL : http://journals.openedition.org/rccsar/546 ; DOI : 10.4000/ rccsar.546 


\section{Lina Coelho}

Centre for Social Studies and School of Economics, University of Coimbra, Portugal

\section{My Money, Your Money, Our Money: Contributions to the Study of Couples' Financial Management in Portugal}

The relationship between conjugality and household financial management has yet to be properly studied in Portugal, particularly in what concerns the ways dominant social norms regarding gender and marriage influence financial behaviour, power relations and resource consumption and sharing by couples. Studies carried out in other countries show that the various systems for managing family accounts are related, in a complex manner, to access to resources, wellbeing and satisfaction of needs of the different family members. This paper aims to contribute to the understanding of this subject in the Portuguese context by discussing the complexity of intrahousehold financial negotiations and decisions. It also presents the preliminary results of a study which, using data from the 2010 Portuguese Institute of Statistics Survey on Income and Living Conditions, applies to Portuguese couples a typology of modes of financial management and control developed by Jan Pahl and Carolyn Vogler.

Keywords: marriage; couples; personal finances; financial management; gender issues; decision-making.

\section{Introduction}

The majority of people live most of their lives in plural households, typically anchored in a couple and sharing common family resources, which have to be managed. Household economic and financial decisions are thus necessarily determined, at least to some extent, by logics of cooperation and sharing, as the needs of all family members have to be taken into account. When a new couple is formed, financial decisions, which were previously made on an individual basis, become shared, a situation that is necessarily reinforced with the birth of children.

As individual preferences are often divergent or even conflicting, couples' decisions result from complex interactions, involving tacit or explicit negotiation between the spouses. This usually leads to the definition, from the outset, of each partner's sphere of decision-making in the management of the joint income, in spending, saving or debt incurrence. Those early decisions define the "rules of the game," and the need (or otherwise) to also negotiate them on a day-to-day basis.

\footnotetext{
* Article published in RCCS 101 (September 2013).

This article was written in the ambit of the project "FINFAM - Finances, Gender and Power: How are Portuguese families managing their finances in the context of the crisis?" (PTDC/IVC-SOC/4823/2012 - FCOMP01-0124-FEDER-029372), financed by EFRD funds through the Operational Programme Factors of Competitiveness (COMPETE), and by national funds through the Foundation for Science and Technology (FCT).
} 
Although many of the deep changes in Portuguese families in recent decades have been thoroughly studied (in terms of socio-demographic and economic aspects, interpersonal relationships, and families' relations with other institutions), the perceptions, negotiations and financial practices of couples have yet to be properly examined. This article aims to fill that gap. It begins by presenting a theoretical contextualization of the ways in which social norms and representations of marriage and gender influence families' financial behaviours, their decisions regarding consumption and saving, intrahousehold sharing of resources, family power relations and individual wellbeing. Then, it undertakes a brief analysis of the Portuguese case, based on data from the 2010 Portuguese Institute of Statistics Survey on Income and Living Conditions (SILC). Although limited in its comprehensiveness and analytical depth, this exercise applies the typology developed by Jan Pahl and Carolyn Vogler on systems of couples' financial management and control, which is the most commonly used typology in empirical studies on this subject.

\section{Household economics and finances: Money, gender and power}

The importance of research on the financial practices of couples has been affirmed in the literature (Dew, 2008). Examining patterns of couples' spending, control of resources and decision-making processes in financial matters is important not only to understand households' economic behaviour, but also to serve as a basis for various kinds of interventions for the promotion of family wellbeing.

Given the widely diverse features of both the families and the contexts in which they operate, couples' financial decisions are a complex issue which has implications for different spheres of family life. Hence, it has become an object of study for various academic disciplines (Dew, 2008; Waseem, 2004).

Mainstream economic theory treats the family as a unit whose members act in perfect harmony in order to maximize the satisfaction of their needs. Therefore, there is supposedly no divergence of interests or preferences within the family, either because there is consensus among its members or because the head of the family, the main breadwinner, can impose his/her own preferences by transferring part of his/her income to the other members of the family (Becker, 1981, 1991). In such a context, the allocation of family resources is invariant to the origin or the identity of the holders of the overall income. 
According to this framework, the family is a "representative economic agent" which, within the limits of the income it has at its disposal; adopts an efficient economic behaviour.

This is a view of the family that does not correspond to many people's experience, since "the prevalence of destructive or wasteful phenomena such as domestic violence and child abuse, as well as the demand for marriage counseling and family therapy, suggests that we consider the possibility that family behavior is sometimes inefficient" (Lundberg and Pollak, 1996: 150).

It is therefore not surprising that models based on game theory have been proliferating in recent economic literature. According to these models, the conjugal interaction is a negotiation between two individuals who have their own individual preferences and differentiated decision-making power, and thus the intrahousehold allocation of resources is determined by the outcome of the "bargaining" game (Lundberg and Pollak, 1996). Still, these approaches are also limited by the formalism of their method of analysis which, by conforming to a rigid framework of hypotheses, results in the selectivity of the object of analysis, making it impossible to generalize the conclusions obtained to various types of family or even to the different stages of life of the same family (Pollak, 1985: 600; Lundberg and Pollak, 2003). Thus, I share the perspective of Sen $(1983,1985,1990)$, who holds that the family should be studied in the framework of a qualitative bargaining theory, centred on the concept of "cooperative conflict." This approach enables us to take into account the role of individual agency and perceptions of the interests, wellbeing, contributions and aspirations of each individual family member.

All negotiations involve the management of individual interests, but in the context of the family, one might expect that they will largely coincide, leading to a cooperation rationale based on altruism and goodwill. Nevertheless, this does not mean the dissolution of selfinterest, or the disappearance of diverse individual motivations and perceptions, as each person's individuality results from multiple identities related to sex, social class, occupational status, race and community of belonging, as well as to his/her position within the family. All these factors influence the way each person perceives their own interests, wellbeing, obligations, objectives and the legitimacy of their behaviour. The perception of self-interest and the perception others have of each person's contribution to the family wellbeing are determining factors in intrahousehold allocation (Sen, 1983, 1985, 1990). Sen underlines the fact that, in some societies, women identify their own individual wellbeing with the family's 
to such an extent that this prevents them from perceiving their own interests in any minimally objective way (Sen, 1990: 126). Furthermore, activities related to the family's survival and reproduction tend to be envisaged as "unproductive," therefore conditioning the social perception of the legitimacy of women claiming for themselves a fair portion of the family income (Sen, 1985: 197). As such, the relative power of men and women in the family depends on the particular social technology ${ }^{1}$ characterizing each community, which determines, inter alia, a specific sexual division of labour and stereotyped perceptions of effort and worthiness. The study of families' economic behaviours should thus recognise that ''maleness' and 'femaleness' matter for the way in which decisions are made and resources allocated" (Katz, 1997: 26). The sources of and entitlements to family income and the ways in which it is managed are thus privileged domains for the expression of social gender roles.

In this regard, it is relevant to distinguish between the management of money and the control of it (Edwards, 1982: 325). The latter corresponds to the decision-making itself, while the former involves the implementation of previously formulated decisions. It is, therefore, the control of money that expresses the power of decision in what concerns family finances.

This interpretation is in accordance with much feminist thought of recent decades, which points to (total or partial) income dependence as a condition for the maintenance of women's subordinate social position (Lister, 1990; O'Connor, 1996; Ward et al., 1993), as "[t]hose in positions with power over others are easily recognized by the fact that they control and have access to resources. Resources give power to control, reward and punish others" (Jarl, 2003: 48).

However, it should be pointed out that access to one's own earnings, and the putative control that results from that, is not automatically converted into power within the family, since (as already mentioned) social representations of gender and marriage do determine the behaviours of men and women, and may result in practices that neutralize or attenuate the conversion of resources into effective power of decision. Hence, it is useful to distinguish between "structural power" and "ideological power." The first is "the power of domination the power to be able to get someone to do what we want, or prevent them from doing other things," while the second consists of the "beliefs, construings, understandings which shape

\footnotetext{
1 "Social technology" is here understood as "the social arrangements that permit productive processes to be carried out," including aspects related to the sexual division of labour (Sen, 1985: 197).
} 
how we think about ourselves and relationships; for example, the different roles, duties and expectations that men and women are guided into in any given society" (Dallos and Dallos, 1997: 10-11). This is an analytically fruitful distinction since it highlights the fact that, even when decisions are not conditioned by violence or restriction of access to resources, the social and cultural conditioning of the choices that each person makes determines the individual's capacity to exercise power (also) within the family. Hence,

[...] differentials in economic power may be reinforced or reduced by ideological power. In families with a traditional division of labour, where wives were non-employed or in part-time work, the ideology of the male breadwinner increased and reinforced the man's economic power. By contrast, in households where women were in full time paid work, and economic resources were more evenly balanced, the ideology of the male breadwinner still limited the power of women. (Pahl, 2007: par. 4.10)

Zelizer $(1994,2003)$ has emphasised the social meanings of money, which is highly differentiated in accordance with its origin, the uses made of it, and the person who has the right to use it. Contrary to mainstream economic discourse, money is not fungible because it is embedded in social relations. In this sense, it is also determined by social gender roles; its applications depend on who has obtained it and how it has been obtained. This idea has been empirically proven in many studies, using databases on household budgets and expenditures in societies with very diverse economic structures and cultural and religious traditions (Hoddinott and Haddad, 1995; Phipps and Burton, 1998; Thomas, 1990, 1993; Lundberg et al., 1997). ${ }^{2}$ Pahl (2000) also analysed the expenditures of British families at the beginning of the 1990s, and concluded that women spent significantly more on food, clothing and education, while men spent more on alcohol, cars, repairs, meals, gambling and holidays. Taking a different perspective, Bajtelsmit and Bernasek (1996) reviewed the literature on financial investments, and found evidence that women allocate their portfolios differently to men, preferring lower-risk options. That is to say, in a couple, who earns the money and how it is obtained determine the way money is applied and who benefits from it (with women tending to give priority to expenses related to the children).

Gender inequalities in the family have been only partially mitigated by the growing contribution of women to family budgets, resulting from their participation in the labour market. In fact, women tend to earn less than men on average, given the prevalence of a wage gender gap, and tend to be penalized for maternity, which leads them to dedicate less

\footnotetext{
${ }^{2}$ See Coelho (2010: 58-63) for more details on this subject.
} 
time to their job - in accordance with prevailing gender roles - at a time when expenses increase significantly (Waldfogel, 1998). Thus, in order to maintain an equitable distribution of resources within the couple when children are born, there has to be a redefinition of the way common monies are managed. If that does not happen, maternity may bring economic hardship for the female partner (Pahl, 2000; Vogler, 1998).

As regards Portugal, there is currently an abundant sociological literature on the ways social representations of gender are manifested in the family and determine the organization of family life (Aboim, 2010; Perista, 2002; Portugal, 2006, 2013; Torres, 2001, 2008; Torres, Guerreiro e Lobo, 2007; Torres et al. 2001; Torres et al., 2004; Wall, 2007; Wall and Amâncio, 2007; Wall and Guerreiro, 2005). Taken together, these studies show that there have been significant developments in gender relations, although they have had non-linear and intricately interconnected results. While the sustained increase of female participation in the labour market in recent decades has been a strong factor in social transformation, with a pronounced impact on gender relations and on family life, there has also been a continuation of "maternalistic values, largely shared by men and women, [which] constitute a fundamental piece in the system of inequality" (Aboim, 2010: 63). Though the model of dual full-time employment has clearly become prevalent in Portuguese families, and there is evidence of growing male participation in household tasks, traditional gender roles still largely prevail, which means that women are burdened with a disproportionate amount of housework and caring tasks. This results in marked inequalities between men and women in actual working time, with women facing increasing difficulties in reconciling their professional, family and personal lives.

In this context, it is to be expected that gender inequalities will also be manifested in the sphere of family financial management.

\section{A typology of systems for managing and controlling family finances}

The works of Jan Pahl and Carolyn Vogler are particularly interesting for their contribution to our understanding of how couples manage household budgets (Pahl, 1980, 1989, 1995, 2008; Vogler, 2005; Vogler et al., 2006; Vogler and Pahl, 1993, 1994). These authors studied British couples (heterosexual, married or cohabiting, and with dependent children), using questionnaires and interviews of varying amplitudes and focuses over the course of three 
decades. The results enabled them to construct typologies on the management and control of family budgets, based on the four main management patterns first proposed by Pahl (1980, 1983): management by one of the spouses; housekeeping allowance; joint management, and independent management. The gradual adaptation of this classification led to an updated version comprising six different categories, of which two correspond to the splitting of previous ones (cf. Chart 1; Pahl, 1983, 1995; Vogler, 1998; Vogler et al., 2006; Vogler, Brockmann and Wiggins, 2008; Vogler and Pahl, 1993, 1994). Based on each spouse's access to money and on their sphere of responsibility in household expenditures, the typology reveals a complex pattern of interrelations between management models, amount and holdership of income, and prevalent gender ideology.

Thus, the housekeeping allowance is typical of couples in which only the man earns a salary and gives his wife a fixed amount to cover daily expenses. The remaining income is managed by him, and it is he who also defines the amount of the allowance. This model has gradually become less common over time.

In the female whole wage model, the husband (predominantly) hands over almost all his wage to his wife so that she can manage it, reserving a small amount for his own personal expenses. The wife is thus entirely responsible for the household budget. This occurs predominantly in low-income families in which managing the household budget is an arduous task because it involves "making ends meet" with resources that are insufficient for the family's needs. The male whole wage system, on the other hand, is characteristic of high-income couples, where the man is the main earner. It may also be associated with practices of domestic violence, in which the wife is subjected to material deprivation.

In the independent management system both partners have their own earnings and are responsible for different categories of the common expenses. This occurs predominantly in middle and upper-middle income families, in young couples or in blended families. It is still quite uncommon but becoming gradually more usual.

In the pooling management model, the spouses have equal access to common money, which they pool, and expenses are the responsibility of both. This is characteristic of couples where the wife also earns a salary. It may take the form of partial pooling if only part of the income for common expenses is pooled and managed jointly. This is the most usual system and has been gaining importance over time. It is also the one that conforms closely to the prevailing ideology of communion in marriage. 


\section{CHART 1: Models of couples' management and control of finances, according to Pahl and Vogler}

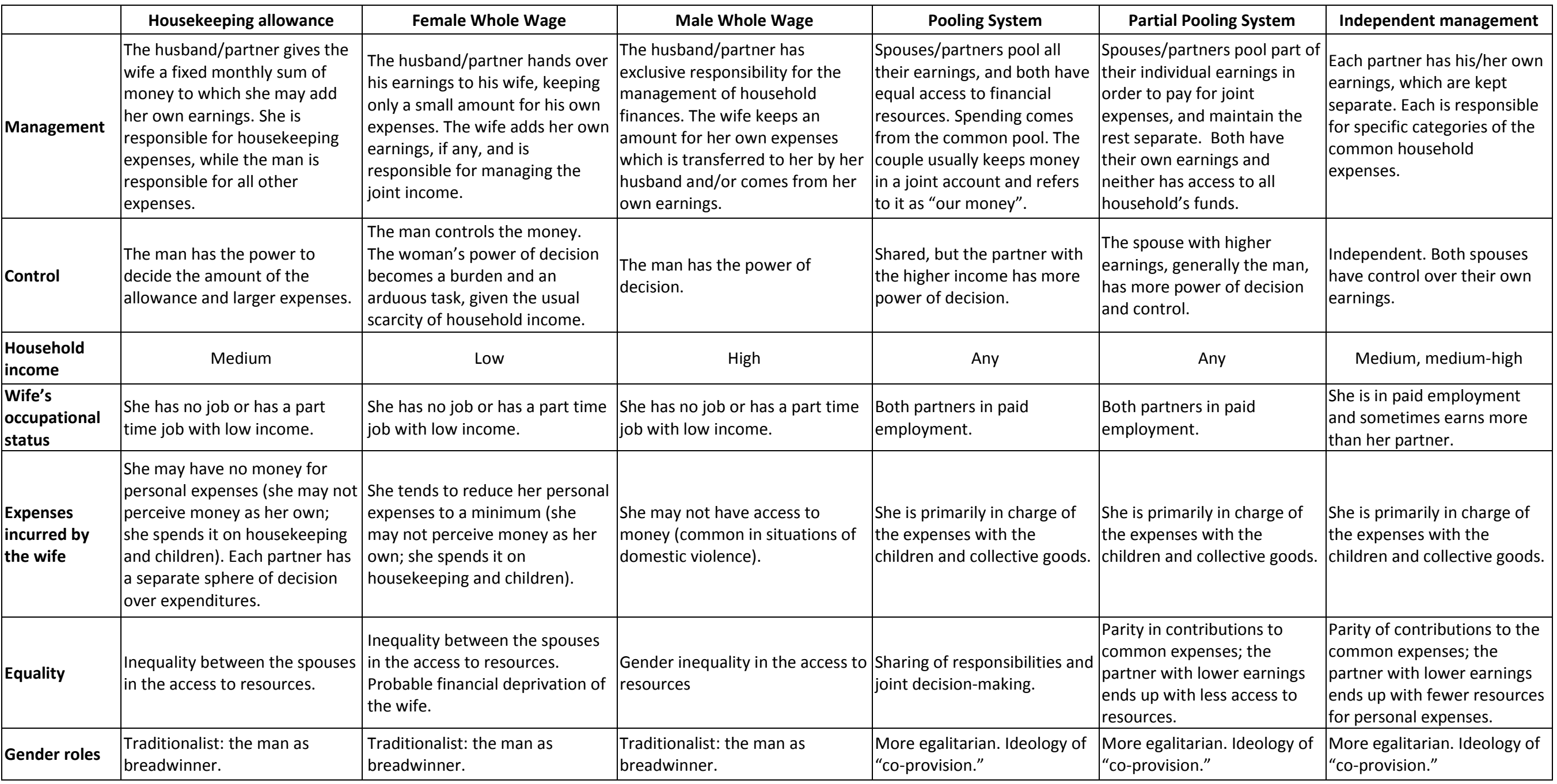

Sources: Pahl (1983); Vogler and Pahl (1993); Vogler (1998); Vogler et al. (2006); Vogler, Brockmann and Wiggins (2008). 
However, pooling of resources does not prevent one of the spouses from having greater control over the family finances. For example, Vogler and Pahl (1993) note that, amongst couples that pool their earnings, only $39 \%$ claimed that both were equally responsible for financial decisions.

Control over money is gauged by each spouse's capacity to decide how it is to be used, to autonomously spend it to satisfy personal needs and/or to make expenditures which are of an exceptional nature or particularly costly. Four systems of control have thus been identified: by the wife, by the husband, shared, and independent.

The level of income and who earns it are related to the way the money is managed and controlled. The person who earns most of the money is the one most likely to control it. However, ideology about gender and marriage may interfere in the option adopted, as do other factors.

In short, the choice of allocation system is influenced by: income (low-income families tend to use systems managed by women); gender ideology or representations (a traditional ideology, in which the man is viewed as the family breadwinner, increases the likelihood of control by the man); relationship with the job market (couples in which only the man has employment, or in which the woman is employed part time or gets low earnings, tend to adopt systems managed by the wife); education levels (more schooling increases the likelihood of sharing resources and decisions); parental socialization (couples' options tend to be influenced by the system used by their parents); and type of family or conjugal relationship (cohabiting couples, those with no children and blended families tend to separate earnings and spheres of expenditure) (Anu, 2011; Burgoyne et al., 2007; Pahl, 1995, 2008; Singh and Morley, 2010; Vogler, 1998; Vogler et al., 2006; Vogler, Lyonette and Wiggins, 2008; Vogler and Pahl, 1993, 1994).

Gender inequality tends to be less pronounced for couples with joint control of pooled money, while it is particularly pronounced in families in which the man controls the finances (Pahl, 1995; Vogler, 1998; Vogler et al., 2006).

Studies carried out in various countries (United States, Australia, Germany, Sweden, Spain) largely confirm the results presented (Ludwig et al., 2011; Pahl, 2008). However, that does not necessarily mean that they can be generalized to other parts of the world (Pahl, 2008). 


\section{Couples' financial management in Portugal: An exploratory approach}

In a study carried out in 1995 by the Institute of Social Sciences, University of Lisbon, the influence of gender roles on the financial decisions of couples was shown by the fact that men mostly took responsibility for managing bank accounts, loans and taxes, while women claimed to decide about the running household expenses in lower value purchases (CIDM, 2001: 59). A few years later, Gomes (2000) undertook an exploratory study on the subject, applying semi-structured interviews to heterosexual couples, and also concluded that representations of marriage and gender do matter in the sphere of family financial management. Older couples tended to use more shared and joint forms of management, as a way of expressing conjugal unity, but this was less common in younger couples or blended families (Gomes, 2000: 166). There were also gender differences in consumption behaviours, with women shouldering more of the everyday household expenses (food, cleaning, clothing) while men took on the expenses with housing (rent or mortgage payment) and other associated bills (water, electricity, gas, telephone). This author detected two conflicting principles in the conjugal experience: individual autonomy and freedom, on the one hand, and family collectivism on the other. However, they never fully cancel each other out, as most couples share resources and decisions to some extent (ibidem: 169). Couples' financial management arrangements are therefore determined by multiple factors, such as the level of individual income, the phase in the life cycle at which the family finds itself, individual psychological characteristics, practical convenience, social gender representations, age, and type of family organization.

Building on the research done so far, this paper aims to identify and typify the modes of financial management and control used by Portuguese couples, based on a secondary source of information - the Survey on Income and Living Conditions (EU-SILC). ${ }^{3}$ This survey, undertaken by the National Institute of Statistics (INE), is a statistical operation carried out by direct interview of a representative sample of household units. It contains a specialized annual module, whose topic in 2010 was precisely the sharing of resources within the household. ${ }^{4}$

\footnotetext{
${ }^{3}$ This survey is performed annually in all countries of the European Union, under the generic title of European Union Statistics on Income and Living Conditions (EU-SILC).

${ }^{4} \mathrm{~A}$ 'household' is understood as the "set of people that reside in the same space and whose fundamental or basic expenses (food, lodging) are borne jointly, irrespective of the existence of kinship bonds; or the person
} 
EU-SILC takes both the household and its individual members as units of observation and analysis. Data concerning the household is obtained by an interview to the person assumed to be the household representative, while data relating to individuals is gathered through personal interviews with each household member aged 16 or over. The survey also collects data on the composition and socio-demographic characteristics of households, as well as the composition, holdership and nature of the household income. In addition, the 2010 survey gathered specific information on the management of all the household income and individuals' power of decision over it.

For the current study, I analysed households consisting of at least one married or cohabiting heterosexual couple, with or without dependent children and living or not with other adults. Households with no income and those in which neither member of the couple managed the common resources were excluded from the sample.

To apply the typology developed by Pahl and Vogler (Pahl, 1989, 2008; Vogler and Pahl, 1993), I analysed data on who earned the couple's income; the way income was handled; the identity of the persons usually responsible for managing the common budget; the share of individual income kept separate from the common budget; and the identity of the person that makes the decisions regarding daily expenses, expenses on durable consumer goods and costly furniture, loans, savings and substantial expenses benefitting the children. Chart 2 sums up the criteria used. Two types of "non-conformity" were found. The first corresponds to one or more contradictions between the responses given by the household's representative and those given by each of the spouses in the individual interviews. ${ }^{5}$ The second corresponds to situations in which responses are inconsistent with at least one of the classification criteria adopted. ${ }^{6}$ In cases in which at least one of these situations was found, the mode of household budget management was classified as "imperfect" (see Chart 2).

that occupies the accommodation entirely, or, when sharing it with others, does not meet the previous condition" (INE, 2010: 10).

${ }^{5}$ This is the case, for example, in households whose representative claims that all income is pooled, but in which at least one of the spouses claims to keep more than $50 \%$ (sometimes even all) of his/her income apart from the common budget.

${ }^{6}$ Examples of this second type of "non-conformity" are found in households in which the wife manages the common resources but has a higher income than her husband. 


\section{CHART 2: Criteria for the classification of households according to the typology of Pahl and Vogler}

\section{Model}

Household questionnaire

Housekeeping allowance

The wife (or maybe the husband) is pointed out as the one who manages the household finances.

The wife is pointed out as the one who manages the household finances.

The wife is pointed out as the one who manages the household finances.

The man is pointed out as the one who manages the household finances.

\section{Male Whole Wage}

The man is pointed out as the one who manages the household's finances.

The earnings are pooled as a common resource; Both spouses manage the common resources.

Part of the earnings are a common resource;

Partial Pooling System Both spouses manage the common part of the resources.

The earnings are (totally or partially) pooled as common resources;

Joint management (imperfect)

Spouses manage the common part of the resources.

Independent management

\section{Individual questionnaires}

Spheres of decision on expenditure are separate (women make the decisions on current expenses and the children, and men decide about exceptional expenses, purchase of durable goods or expensive furniture, credits and savings);

The wife has low income or no income at all.

Both spouses declare that less than $50 \%$ of their own personal income is kept separate;

The wife has low earnings or no earnings at all.

Both spouses declare that they decide equally often for all spheres of expenditure;

Both spouses agree that the man decides in one or more spheres of expenditure (although this is not a housekeeping allowance system).

Both spouses declare that at least $50 \%$ of their own personal earnings is kept separate.

Both spouses declare that they decide equally often for all spheres of expenditure

Both spouses agree that the woman decides in one or more spheres of expenditure (although this is not a housekeeping allowance system).

Both spouses may take funds from the bank accounts for their personal use, including from those that are not in their name.

At least one of the spouses declares to keep up to $50 \%$ of his/her personal income separate;

Although all earnings are a common resource, at least one of the spouses may not take funds from the bank accounts.

They declare that only part of the earnings is common resources. However, no part of the personal income is kept separate;

At least one of the spouses keeps more than $50 \%$ or all his/her income separate. 
Table 1 summarizes the results obtained. Most Portuguese couples claim to pool their income and treat it as a common resource (78.5\%); the group that considered only part of the income to be a common resource was much smaller (18.8\%); and only a small number of couples claimed to manage their individual incomes in a fully separate manner (2.7\%).

Table 1: Household Management Systems

\begin{tabular}{|c|c|c|c|c|}
\hline How is income conceived of? & $\mathbf{N}$ & $\%$ & $\begin{array}{l}\text { Per Capita Adult } \\
\text { Equivalent Income* } \\
(€)\end{array}$ & $\begin{array}{l}\text { Minimum monthly } \\
\text { income for expenses } \\
\text { and financial } \\
\text { commitments }(€)\end{array}$ \\
\hline All income as common resources & 2,694 & 78.5 & $10,290.2(7795.3)$ & $1,410.6(810.7)$ \\
\hline $\begin{array}{l}\text { Some income as common resources and } \\
\text { the rest as individual resource }\end{array}$ & 645 & 18.8 & 11,814.4 (7975.9) & $1525.3(904.2)$ \\
\hline $\begin{array}{l}\text { All income belongs to the person who } \\
\text { earned it }\end{array}$ & 94 & 2.7 & $10,889.8(6231.1)$ & 1820.4 (977.1) \\
\hline \multicolumn{5}{|l|}{ Management System } \\
\hline Housekeeping Allowance & 111 & 3.2 & $9,951.3(6936.7)$ & $1,166.8(640.1)$ \\
\hline Female Whole Wage & 185 & 5.4 & $8,546.4(5022.8)$ & $1,131.3(560.5)$ \\
\hline Female Whole Wage (imperfect) & 185 & 5.4 & $10,520.3(8158.3)$ & $1,383.4(743.8)$ \\
\hline Male Whole Wage & 149 & 4.3 & $10,322.6(8792.0)$ & $1,329.9(873.3)$ \\
\hline Male Whole Wage (imperfect) & 496 & 14.4 & $11,041.7(8976.7)$ & 1,448.1 (845.9) \\
\hline Pooling System & 1247 & 36.21 & $10,532.1(7525.6)$ & $1,491.0(832.8)$ \\
\hline Partial Pooling System & 495 & 4.4 & $10,231.2(7295.0)$ & $1,389.7(760.1)$ \\
\hline Pooling System (imperfect) & 475 & 13.8 & $11,138.8(7140.7)$ & $1,518.0(943.6)$ \\
\hline Independent Management & 104 & 3.0 & $10,697.3(6369.6)$ & $1,792.6(944.2)$ \\
\hline
\end{tabular}

* Using the modified OECD equivalence scale. Standard errors in brackets.

The findings show a pattern of distribution that is broadly identical to that of the EU countries as a whole, though there is significant variability in specific figures per country. Portugal shows median figures in the European context (Eurostat, 2012). ${ }^{7}$ This regularity confirms the prevalence of values and practices supporting the pooling of resources within marriage, which cuts across European societies, despite national modulations.

\footnotetext{
${ }^{7}$ These conclusions refer to the total sample of the survey, which is broader than the sub-sample in the current study. However, the relative orderings are not likely to differ significantly in both cases.
} 
As regards management arrangements, joint management (whether total or partial) is the most widely used (64.4\%). However, it is less common in blended families, where only $28 \%$ of the couples claim to share and manage all or part of their income jointly, while as much as $11.7 \%$ maintain their own earnings entirely separate from the common pool, as compared to only $2.7 \%$ of the other types of families.

Whole wage systems are used by $29.5 \%$ of households, with male whole wage being more common (18.7\%) than female whole wage (10.8\%). Housekeeping allowances and independent management show similar figures (around 3\%).

These results are broadly in agreement with those presented in the literature for other countries. Still, shared management systems show greater expression in Portugal, while housekeeping allowances and independent management are residual when compared to other countries.

The average figures on household income and expenditures presented in the two righthand columns of Table 1 also seem to confirm some well-known regularities. Thus, housekeeping allowance and female whole wage systems appear to be associated with lowincome and low-expenditure families. This is an aspect that deserves further analysis in future research.

Inconsistencies between answers given by the spouse that responded to the questionnaire as household representative and answers given by each spouse to the individual questionnaires were found in $33.6 \%$ of the couples. These situations were classified as "imperfect arrangements" as they do not fully comply with the criteria used to define each of the different systems. ${ }^{8}$ These situations occur with respect to the whole wage (19.8\%) and (total or partial) joint management systems (13.8\%). Although this may be due to errors of perception by interviewees or to recording inadequacies, the figures are expressive enough to require further attention, particularly in order to understand to what extent discrepancies are due either to possibly dissonant perceptions of each spouse regarding gender and/or marriage roles, or to factors of another nature, such as incomplete knowledge by one of the spouses of the household's income and/or financial situation.

\footnotetext{
${ }^{8}$ These types of difficulties in using the typology have also been mentioned by other authors, who suggest as possible explanations the fact that the categories used are not mutually exclusive, the fact that some individuals interpret the questions idiosyncratically, and the lack of similarity between the classification criteria used and the pattern of responses actually given by some couples (Ashby and Burgoyne, 2008; Bennett, 2013; Evertsson and Nyman, 2012).
} 


\section{Conclusion}

Based on a representative database of the Portuguese population, the findings presented here are part of a pioneering study on household financial management practices in Portugal. Although there is a wide range of conjugal income management arrangements, typologies have proved to be a useful methodological tool in this area, as the work of Jan Pahl and Carolyn Vogler has demonstrated. The preliminary results presented above suggest a pattern that is in line with the existing literature in this field. Still, further study is required in order to clarify some specific aspects of the Portuguese case.

Some particular features of Portuguese families may indeed influence couples' choices regarding financial management matters. Factors such as a high prevalence of couples in which both partners are in full-time employment, or the strong role of intra-family solidarity in the provision of social protection in the Portuguese context (Santos, 1993; Hespanha, 1995; Portugal, 2006, 2013) may explain some of the differences in the patterns of choice referred to above.

This is a complex issue, which requires interdisciplinary research approaches, combining complementary perspectives and methods of analysis, in order to better understand negotiation strategies between husbands and wives as well as to establish systematic patterns of relation among different family structures, contexts and arrangements. Such paths of research should also lead to correlations between household financial management choices and financial stability, intrafamily equity in the access to resources and satisfaction with conjugal and family life.

This research agenda is particularly important in the context of the current economic crisis, as Portuguese families are being forced to revise and adapt their management practices in order to deal with increased budgetary constraints. One may also expect that adjustments to expenditure and living standards will affect women more intensely than men (particularly mothers of dependent children) since, in keeping with traditional gender roles, women may tend to accommodate more to the constraints of austerity, particularly in families in which gender inequality was greater at the outset. 


\section{References}

Aboim, Sofia (2010), "A vida familiar no masculino: negociando velhas e novas masculinidades," in Karin Wall, Sofia Aboim e Vanessa Cunha (eds.), Género, família e mudança em Portugal. Lisboa: Comissão para a Igualdade no Trabalho e no Emprego (CITE), 39-66.

Anu, Raijas (2011), "Money Management in Blended and Nuclear Families," Journal of Economic Psychology, 32: 556-563.

Ashby, Katherine; Burgoyne, Carole (2008), "Separate Financial Entities? Beyond Categories of Money Management," Journal of Socio-Economics, 37: 458-480.

Bennet, Fran (2013), "Researching Within-Household Distribution: Overview, Developments, Debates, and Methodological Challenges," Journal of Marriage and Family, 75: 582-597.

Bajtelsmit, Vickie; Bernasek, Alexandra (1996), "Why Do Women Invest Differently than Men?" Financial Counseling and Planning, 7: 1-10.

Becker, Gary (1981), A Treatise on the Family. Cambridge, Massachusetts: Harvard University Press.

Becker, Gary (1991), A Treatise on the Family (enlarged edition). Cambridge, Massachusetts: Harvard University Press.

Burgoyne, Carole; Reibstein, Janet; Edmunds, Anne; Dolman, Valda (2007), "Money Management Systems in Early Marriage: Factors Influencing Change and Stability," Journal of Economic Psychology, 28: 214-228.

CIDM - Comissão para a Igualdade e para os Direitos das Mulheres (2001), Portugal, situação das mulheres, 2001. Lisboa: CIDM.

Coelho, Lina (2010), "Mulheres, família e desigualdade em Portugal." PhD Dissertation in Economics. Coimbra: Universidade de Coimbra. Accessed on 21.06.2013, at https://estudogeral.sib.uc.pt/handle/10316/13833.

Dallos, Sally; Dallos, Rudi (1997), Couples, Sex and Power: the Politics of Desire. Buckingham: Open University Press.

Dew, Jeffrey (2008), "Marriage and Finances," in Jing Xiao (ed.) Handbook of Consumer Finance Research. New York: Springer, 337-350.

Edwards, Meredith (1982), "Financial Arrangements Made by Husbands and Wives: Findings of a Survey," Journal of Sociology, 18: 320-338.

Eurostat (2012), "2010 EU-SILC Module on intra-household sharing of resources: Assessment of the implementation." Accessed on 08.07.2013, at http://epp.eurostat.ec.europa.eu/portal/page/portal/income social inclusion living conditions/ documents/tab7/Assessment.pdf.

Evertsson, Lars; Nyman, Charlott (2012), "Perceptions and Practices in Independent Management: Blurring the Boundaries between 'Mine', 'Yours' and 'Ours'," Journal of Family Economic Issues, 33: 389-506.

Gomes, Catarina (2000), "Quotidianos conjugais: a decisão financeira como forma de poder," Forum Sociológico, 3-4(II Series): 157-178.

Hespanha, Pedro (1995), "A construção da habitação em meio rural: um domínio da sociedadeprovidência," Revista Crítica de Ciências Sociais, 42: 125-153.

Hoddinott, John; Haddad, Lawrence (1995), "Does Female Income Share Influence Household Expenditures? Evidence from Côte d'Ivoire," Oxford Bulletin of Economics and Statistics, 57(1): 7796. 
INE - Instituto Nacional de Estatística (2010), Módulo ICOR 2010 - Partilha de recursos no seio do agregado doméstico privado 2010: Documento metodológico. Accessed on 27.06.2013, at http://smi.ine.pt/UploadFile/Download/528.

Jarl, Ann-Cathrin (2003), In Justice: Women and Global Economics. Minneapolis: Fortress.

Katz, Elizabeth (1997), "The Intra-Household Economics of Voice and Exit," Feminist Economics, 3(3): 25-46.

Lister, Ruth (1990), "Women, Economic Dependency and Citizenship," Journal of Social Policy, 19(4): 445-467.

Ludwig-Mayerhofer, Wolfgang; Allmendinger, Jutta; Hirseland, Andreas; Schneider, Werner (2011), "The Power of Money in Dual-earner Couples: A Comparative Study," Acta Sociologica, 54(4): 367383.

Lundberg, Shelly; Pollak, Robert (1996), "Bargaining and Distribution in Marriage," Journal of Economic Perspectives, 10(4): 139-158.

Lundberg, Shelly; Pollak, Robert (2003), "Efficiency in Marriage," Review of Economics of the Household, 1: 153-167.

Lundberg, Shelly; Pollak, Robert; Wales, Terence (1997), "Do Husbands and Wives Pool Their Resources? Evidence from the United Kingdom Child Benefit," The Journal of Human Resources, 32(3): 463-480.

O'Connor, Julia (1996), "From Women in the Welfare State to Gendering Welfare State Regimes," Current Sociology, 44(2): 1-130.

Pahl, Jan (1980), "Patterns of money management within marriage," Journal of Social Policy, 9: 313335.

Pahl, Jan (1983), "The Allocation of Money and the Structuring of Inequality within Marriage," The Sociological Review, 31(2): 237-262.

Pahl, Jan (1989), Money and Marriage. London: Macmillan.

Pahl, Jan (1995), "His Money, Her Money: Recent Research in Financial Organisation in Marriage," Journal of Economic Psychology, 16(3): 361-376.

Pahl, Jan (2000), "The Gendering of Spending within Households," Radical Statistics, 75(Autumn): 3848.

Pahl, Jan (2007), "Power, Ideology and Resources Within Families: A Theoretical Context for Empirical Research on Sleep," Sociological Research Online, 12(5). Accessed on 09.10.2009 at http://www.socresonline.org.uk/12/5/12.html.

Pahl, Jan (2008), "Family Finances, Individualisation, Spending Patterns and Access to Credit," Journal of Socio-Economics, 37: 577-591.

Perista, Heloísa (2002), "Género e trabalho não pago: os tempos das mulheres e os tempos dos homens," Análise Social, XXXVII(163): 447-474.

Phipps, Shelley; Burton, Peter (1998), "What's Mine is Yours? The Influence of Male and Female Incomes on Patterns of Household Expenditure," Economica, 65: 599-613.

Pollak, Robert (1985), "A Transaction Cost Approach to Families and Households," Journal of Economic Literature, 33: 581-608.

Portugal, Sílvia (2006), "Women, Welfare State and Welfare Society in Portugal," in Maria Mesner \& Gudrun Wolfgruber (eds.), The Policies of Reproduction at the Turn of the 21st Century. Innsbruck: StudienVerlag, 41-54. 
Portugal, Sílvia (2013), Família e redes sociais: Ligações fortes na produção de bem-estar. Coimbra: Almedina.

Santos, Boaventura de Sousa (1993), "O Estado, as relações salariais e o bem-estar social na semiperiferia: o caso português," in Boaventura de Sousa Santos (ed.), Portugal: um retrato singular. Porto: Edições Afrontamento, 17-56.

Sen, Amartya (1983), "Economics and the Family," Asian Development Review, 1(2): 15-26.

Sen, Amartya (1985), "Women, Technology and Sexual Divisions," Trade and Development. An UNCTAD Review, 6: 195-223.

Sen, Amartya (1990), "Gender and Cooperative Conflicts," in Irene Tinker (ed.), Persistent Inequalities: Women and World Development. Oxford: Oxford University Press, 123-149.

Singh, Supriya; Morley, Clive (2010), "Gender and Financial Accounts in Marriage," Journal of Sociology, 47(1): 3-16.

Thomas, Duncan (1990), "Intrahousehold Resource Allocation: an Inferential Approach," Journal of Human Resources, 25(4): 635-664.

Thomas, Duncan (1993), "The Distribution of Income and Expenditure Within the Household," Annales d'Économie et de Statistique, 29: 109-136.

Torres, Anália (2001), "Casamento e género: mudança nas famílias contemporâneas a partir do caso português," Revista Intersecções, 3: 53-70.

Torres, Anália (2008), "Women Gender and Work. The Portuguese in the Context of the European Union," International Journal of Sociology, 38(4): 36-56.

Torres, Anália; Silva, Fernando V.; Monteiro, Teresa L.; Cabrita, Miguel; Jesus, F. (2001), "Trabalho e Vida Familiar: problemas, soluções e perplexidades," Cadernos de Política Social: Redes e Políticas de Solidariedade, 2-3: 29-48.

Torres, Anália; Cabrita, Miguel; Silva, Fernando V.; Monteiro, Teresa L. (2004), Homens e mulheres entre família e trabalho. Lisboa: Comissão para a Igualdade no Trabalho e no Emprego (CITE).

Torres, Anália; Guerreiro, Maria das Dores; Lobo, Cristina (2007), "Famílias em mudança. configurações, valores e processos de recomposição," in Maria das Dores Guerreiro, Anália Torres and Luís Capucha (eds.), Quotidiano e qualidade de vida. Oeiras: Celta Editora, 7-37.

Vogler, Carolyn (1998), "Money in the Household: Some Underlying Issues of Power," Sociological Review, 46(4): 687-713.

Vogler, Carolyn (2005), "Cohabiting Couples: Rethinking Money in the Household at the Beginning of the Twenty First Century," The Sociological Review, 53: 1-29.

Vogler, Carolyn; Brockmann, Michaela; Wiggins, Richard (2006), "Intimate Relationships and Changing Patterns of Money Management at the Beginning of the Twenty-First Century," The British Journal of Sociology, 57(3): 455-482.

Vogler, Carolyn; Brockmann, Michaela; Wiggins, Richard (2008), "Managing Money in New Heterosexual Forms of Intimate Relationships," Journal of Socio-Economics, 37(2): 552-576.

Vogler, Carolyn; Lyonette, Clare; Wiggins, Richard (2008), "Money, Power and Spending Decisions in Intimate Relationships," The Sociological Review, 56(1): 117-143.

Vogler, Carolyn; Pahl, Jan (1993), "Social and Economic Change and the Organization of Money in Marriage," Work, Employment and Society, 7: 71-95.

Vogler, Carolyn; Pahl, Jan (1994), "Money, Power and Inequality within Marriage," The Sociological Review, 42(2), 263-289. 
Waldfogel, Jane (1998), "The Family Gap for Young Women in the United States and Britain: Can Maternity Leave Make a Difference?" Journal of Labor Economics, 16(3): 505-545.

Wall, Karin (2007), "Atitudes face à divisão familiar do trabalho em Portugal e na Europa," in Karin Wall \& Lígia Amâncio (eds.), Família e género em Portugal e na Europa. Lisboa: Imprensa de Ciências Sociais, 211-257.

Wall, Karin; Amâncio, Lígia (2007), "Família e género, atitudes sociais dos Portugueses," in Karin Wall \& Lígia Amâncio (eds.), Família e género em Portugal e na Europa. Lisboa: Imprensa de Ciências Sociais, 35-91.

Wall, Karin; Guerreiro, Maria das Dores (2005), “A divisão familiar do trabalho," in Karin Wall (ed.), Famílias em Portugal - Percursos, interacções, redes sociais. Lisboa: Imprensa de Ciências Sociais, 303-362.

Ward, Clare; Heather, Joshi; Dale, Angela (1993), "Income Dependency within Couples," National Child Development Study Working Paper 36. London: Social Statistics Research Unit. Accessed on 08.07.2013, at http://www.cls.ioe.ac.uk/library-media\%5Cdocuments\%5Cusgwp36.pdf.

Waseem, Saba (2004), "Household Monies and Decision-Making," FaHCSIA Policy Research Paper, 23. Accessed on 20.06.2013, at http://www.fahcsia.gov.au/sites/default/files/documents/05 2012/prp23.pdf.

Zelizer, Viviana (1994), The Social Meaning of Money. Harper Collins: New York.

Zelizer, Viviana (2003), "O significado social do dinheiro - Dinheiros especiais," in João Peixoto \& Rafael Marques (eds.), A Nova Sociologia Económica. Lisboa: Celta, 125-165. 